\title{
Evaluation of Soil Potassium Test to Improve Fertilizer Recommendations for Corn
}

\author{
Manbir K. Rakkar, David W. Franzen, Amitava Chatterjee \\ Soil Science Department, North Dakota State University, Fargo, USA \\ Email: manbir.rakkar@ndsu.edu
}

Received 29 April 2015; accepted 24 May 2015; published 28 May 2015

Copyright (C) 2015 by authors and Scientific Research Publishing Inc.

This work is licensed under the Creative Commons Attribution International License (CC BY). http://creativecommons.org/licenses/by/4.0/

c) (i) Open Access

\section{Abstract}

The soil potassium $(\mathrm{K})$ test methodology is under increased evaluation due to the soil sample drying effect, temporal variations of test results and inconsistent crop response to applied $\mathrm{K}$ fertilizers. Ten on-farm trials were conducted in 2014 in eastern North Dakota to determine the corn response to different $\mathrm{K}$-fertilizer rates and to assess the variation of soil $\mathrm{K}$ test levels between airdried (KDry) and field moist (KMoist) soil samples during the corn growing season. Significant differences were observed between KDry and KMoist soil $\mathrm{K}$ test results. The ratio of KDry/KMoist showed high correlation with cation exchange capacity $(r=0.63, p<0.10)$, Organic matter $(r=$ $0.61, \mathrm{p}<0.10)$ and $(\mathrm{Ca}+\mathrm{Mg}) / \mathrm{K}$ ratio $(\mathrm{r}=0.64, \mathrm{p}<0.10)$ from the $1 \mathrm{M}$ ammonium acetate extractant, while $\mathrm{pH}$, electrical conductivity, clay (\%), and soil moisture showed non-significant correlation. On average, KDry resulted in higher soil $\mathrm{K}$ test levels than KMoist and pattern of deviation was different for surface and sub-surface soil samples. Soil $\mathrm{K}$ analysis of samples collected during the fall and spring showed large enough variations to affect the soil test interpretation category which was used to make fertilizer recommendations. Corn yield increased significantly with applied $\mathrm{K}$ fertilizer at only three out of 8 sites with beginning $\mathrm{K}$ levels below the current critical level of $150 \mathrm{ppm}$, and one response was at a site with $\mathrm{K}$ level above the critical level. Therefore, use of either the KDry or KMoist method alone may not be adequate to predict $\mathrm{K}$ response in some North Dakota soils.

\section{Keywords}

Potassium, Soil Test Methodology, Fertilizer Recommendations, Grain Yield

\section{Introduction}

The corn (Zea mays) growing belt of the United States is shifting north and west of the traditional Corn Belt due 
to changing climate patterns and improved corn hybrid varieties with short-season yield potential. Corn yields have increased more than two folds in North Dakota in past three decades [1]. The increase in corn yield in North Dakota is the net result of improved corn genetics and higher rainfall during the growing season [2]. Since higher yields are often accompanied with high nutrient removal from the soil [3], maintaining an adequate supply of nutrients is the next major challenge for the corn growers of North Dakota.

Providing an adequate supply of nutrients to corn is important for gaining yield benefits from other management practices. Corn is known to take up substantial amounts of $\mathrm{K}$ during the growing season. For instance, corn yielding $10.11 \mathrm{Mt} / \mathrm{ha}$ can accumulate about $165 \mathrm{~kg} \cdot \mathrm{ha}^{-1}$ of potassium [4]. Crop response to $\mathrm{K}$ is not as great as that of N, but K plays a vital role in every facet of crop growth. Positive correlation has been reported among K content of crops and photosynthesis, carbohydrate metabolism, lodging and disease resistance [5]. Potassium plays an important role in water uptake and helps in maintenance of yields in adverse climatic conditions such as drought [6]-[8]. Therefore, maintaining an adequate level of $\mathrm{K}$ is important in the rain-fed agricultural system of North Dakota.

Soil testing is an important diagnostic tool for estimating nutrient supplying capacity of soils for growing crops. The most widely used procedure for estimating plant-available potassium is extraction of $\mathrm{K}$ from air-dried soil samples using $1 \mathrm{M}$ ammonium acetate [9]. However, air-drying of soil samples is known to collapse or scroll up the clay lattice structure leading to release or entrapment of $\mathrm{K}$ depending upon soil solution $\mathrm{K}$ concentration and clay mineralogy [10], which can lead to over- or under-estimation of soil-K levels [11]. To overcome this issue, Iowa State University has reintroduced the procedure of using field-moist soil samples for plant-available $\mathrm{K}$ analysis. Analysis of field-moist soil samples from Iowa for available $\mathrm{K}$ has resulted in improved correlation with corn yields compared with air-dried soil $\mathrm{K}$ analysis [12]. Therefore, performance of this new methodology needs to be reviewed with the soils of North Dakota.

Soil K results not only are subject to change due to the air-drying of soil samples, but also may vary depending on the date of sampling [13]. The seasonality effect is likely due to seasonal variability in moisture (high moisture in winters and comparatively low moisture towards the end of growing season when soils are driest), $\mathrm{K}$ leaching from crop residues, freezing and thawing, and microbial activity [14]. Switching from fall to spring sampling can lead to significant changes in soil $\mathrm{K}$ values, affecting the rate of K-fertilizer application [15]. Therefore, a better understanding of fluctuations of soil $\mathrm{K}$ level during the growing season will be helpful in improving K-fertilizer recommendations.

In North Dakota, fertilizer recommendations for corn were formulated in the late 1970s and early 1980s when yields were much lower than they are today. The new corn varieties for the region are much more productive and generally soil tests $\mathrm{K}$ levels are much lower today.

To address the increase in corn acres in North Dakota, the relevance of the current soil $\mathrm{K}$ test and response of modern corn hybrids to $\mathrm{K}$ fertilizer, a study was conducted with three main objectives:

1) To compare soil $K$ test values based on air-dried and field moist samples;

2) To determine the effect of sampling time on soil $K$ test levels during the corn growing season;

3) To determine the corn response to applied K-fertilizer based on the predictability of the soil K test.

\section{Materials and Methods}

\subsection{Site Descriptions}

During 2014, trials were conducted at ten locations in the eastern part of North Dakota including the Cass, Barnes, Richland and Sargent counties (Figure 1). All of these sites are involved in agricultural production with corn and soybean as the main crops. These areas have a humid-continental climate with mean precipitation about $55 \mathrm{~cm}$ and mean temperature varying about $5^{\circ} \mathrm{C}$ (Mean of temperature and precipitation from 1981 to 2010).

Soil series descriptions are listed in Table 1. Most of these soils are developed from glacial lacustrine sediments, glacial outwash or till/moraines with somewhat poorly drained to well drained characteristics.

\subsection{Experimental Design}

Each experimental location was established with a minimum distance of $30 \mathrm{~m}$ from the field edge. The experimental design of the trials was a randomized complete block design with six K-fertilizer treatments and four 


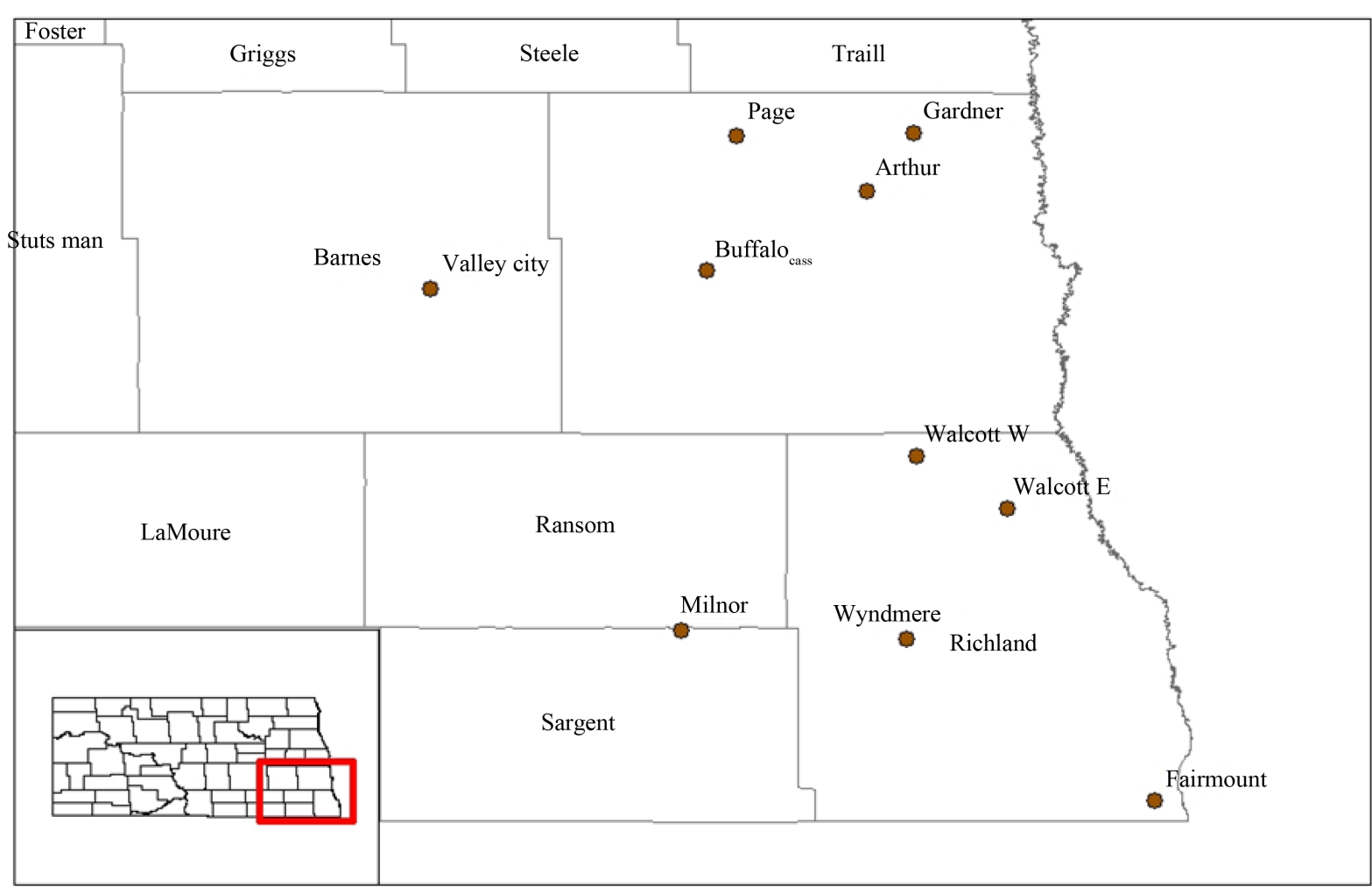

Figure 1. North Dakota map showing experimental sites of 2014.

Table 1. Location and soil characterization information of K-experimental sites.

\begin{tabular}{|c|c|c|c|}
\hline Location & Latitude and longitude & Soil series & Taxonomic classification \\
\hline Buffalo & $\begin{array}{l}46^{\circ} 55^{\prime} 12.582^{\prime \prime} \mathrm{N} \\
97^{\circ} 25^{\prime} 18.338^{\prime \prime} \mathrm{W}\end{array}$ & Lankin-Gilby & $\begin{array}{l}\text { Fine-loamy, mixed, superactive, } \\
\text { frigid Pachic Hapludolls }\end{array}$ \\
\hline Gardner & $\begin{array}{l}47^{\circ} 09^{\prime} 57.830^{\prime \prime} \mathrm{N} \\
97^{\circ} 03^{\prime} 04.561^{\prime \prime} \mathrm{W}\end{array}$ & Galchutt & $\begin{array}{l}\text { Fine, smectitic, frigid } \\
\text { Vertic Argialbolls }\end{array}$ \\
\hline Walcott E & $\begin{array}{l}46^{\circ} 29^{\prime} 43.090^{\prime \prime} \mathrm{N} \\
96^{\circ} 53^{\prime} 05.196^{\prime \prime} \mathrm{W}\end{array}$ & Wheatville-Mantador-Delamere & $\begin{array}{c}\text { Coarse-silty over clayey, mixed } \\
\text { over smectitic, superactive, frigid } \\
\text { Aeric Calciaquolls }\end{array}$ \\
\hline Wyndmere & $\begin{array}{l}46^{\circ} 15^{\prime} 38.809^{\prime \prime} \mathrm{N} \\
97^{\circ} 03^{\prime} 50.155^{\prime \prime} \mathrm{W}\end{array}$ & Glyndon & $\begin{array}{l}\text { Coarse-silty, mixed, superactive, } \\
\text { frigid Aeric Calciaquolls }\end{array}$ \\
\hline Fairmount & $\begin{array}{l}45^{\circ} 58^{\prime} 18.719^{\prime \prime} \mathrm{N} \\
96^{\circ} 37^{\prime} 08.665^{\prime \prime} \mathrm{W}\end{array}$ & Gardena & $\begin{array}{l}\text { Coarse-silty, mixed, superactive, } \\
\text { frigid Pachic Hapludolls }\end{array}$ \\
\hline Milnor & $\begin{array}{l}46^{\circ} 16^{\prime} 33.843^{\prime \prime} \mathrm{N} \\
97^{\circ} 28^{\prime} 01.110^{\prime \prime} \mathrm{W}\end{array}$ & Embden-Wyndmere & $\begin{array}{l}\text { Coarse-loamy, mixed, superactive, } \\
\text { frigid Pachic Hapludolls }\end{array}$ \\
\hline Walcott W & $\begin{array}{l}46^{\circ} 35^{\prime} 16.546^{\prime \prime} \mathrm{N} \\
97^{\circ} 02^{\prime} 50.090^{\prime \prime} \mathrm{W}\end{array}$ & Hecla-Garborg & $\begin{array}{c}\text { Sandy, mixed, frigid Oxyaquic } \\
\text { Hapludolls }\end{array}$ \\
\hline Arthur & $\begin{array}{l}47^{\circ} 03^{\prime} 46.590^{\prime \prime} \mathrm{N} \\
97^{\circ} 08^{\prime} 03.730^{\prime \prime} \mathrm{W}\end{array}$ & Glyndon-Tiffany & $\begin{array}{l}\text { Coarse-silty, mixed, superactive, } \\
\text { frigid Aeric Calciaquolls }\end{array}$ \\
\hline Valley city & $\begin{array}{l}46^{\circ} 53^{\prime} 17.843^{\prime \prime N} \\
97^{\circ} 54^{\prime} 54.062^{\prime \prime} \mathrm{W}\end{array}$ & Barnes-Svea & $\begin{array}{l}\text { Fine-loamy, mixed, superactive, } \\
\text { frigid Calcic Hapludolls }\end{array}$ \\
\hline Page & $\begin{array}{l}47^{\circ} 09^{\prime} 38.226^{\prime \prime} \mathrm{N} \\
97^{\circ} 22^{\prime} 02.788^{\prime \prime} \mathrm{W}\end{array}$ & Swenoda & $\begin{array}{l}\text { Coarse-loamy, mixed, superactive, } \\
\text { frigid Pachic Hapludolls }\end{array}$ \\
\hline
\end{tabular}


replications. Nine of the total sites received a fertilizer application of potassium chloride- $\mathrm{KCl}(0-0-60)$ at the rate of $0,33.6,67.2,100.9,134.5,168.1 \mathrm{~K}_{2} \mathrm{O} \mathrm{kg} \cdot \mathrm{ha}^{-1}$ while the Milnor site received $\mathrm{K}$ application of $0,67.2,134.5$, $201.7,269.0,336.2 \mathrm{~K}_{2} \mathrm{O} \mathrm{kg} \cdot \mathrm{ha}^{-1}$. Dimensions of all plots were $9.14 \mathrm{~m}$ long by $3.05 \mathrm{~m}$ wide, with a $1.52 \mathrm{~m}$ of alley between each replication. The alleyways were cut out when the corn had $8-12$ leaves. Corn planting and all agronomic and cultural operations were carried out by the farmers and were uniform for all plots within a location (Table 2). The farmer did not apply $\mathrm{K}$ fertilizer within the boundaries of experimental plots. When the grower applied $\mathrm{K}$ with $\mathrm{N}$ or $\mathrm{P}$ fertilizer, the plot area was excluded from his field application and $\mathrm{N}, \mathrm{P}$ and any other nutrients determined necessary by the pre-plant soil test were broadcast applied by the researchers.

\subsection{Soil Sampling}

Initial composite soil samples were collected from $0-15 \mathrm{~cm}$ depth from each site before planting and were analyzed for plant available nutrients and other basic soil properties. During the growing season, soil samples were collected from the control plots (plots with no K-fertilizer application) twice each month with an interval of about 15 days. A $2.5 \mathrm{~cm}$ diameter Hofer soil tube was used to take the samples from the $0-15 \mathrm{~cm}$ and $15-30$ $\mathrm{cm}$ depth throughout the growing season. Soil samples were not taken from $15-30 \mathrm{~cm}$ on the second August sampling at Page and Valley City due to soil hardness. Soil samples were collected by taking four to five cores at each depth from the interior inter-row area within each plot. Samples from each depth were then composited and stored in zip-lock polythene bags to maintain the moisture level comparable to the field conditions. Samples were transported in a cooler to the laboratory and stored in laboratory refrigerator at $7^{\circ} \mathrm{C}$ for one to three weeks.

\subsection{Laboratory Analysis}

Initial soil samples-Initial composite soil samples were analyzed for $\mathrm{pH}, \mathrm{N}, \mathrm{P}, \mathrm{K}, \mathrm{EC}$ and organic matter by the NDSU Soil and Water Testing Laboratory using approved methods for the North Central Region of the USA (Table 3). Soil texture was determined by a hydrometer method [16]. Cation exchange capacity of the soil was determined by saturating the soil with $1 \mathrm{M}$ sodium acetate solution and then washing the soil with $90 \%$ ethanol solution and replacing the sodium ions from exchange complex using $1 \mathrm{M}$ ammonium acetate [17].

Methodology for KDry (plant-available-K test of air-dried soil samples) and KMoist (plant-available-K test of field-moist soil samples)-Each soil sample was thoroughly mixed and subdivided into two sub-samples. One of them was analyzed with standard procedure of soil $\mathrm{K}$ test which involves air-drying of soil, grinding and passing through $2 \mathrm{~mm}$ sieve. Two grams of air-dried sample was extracted with $20 \mathrm{ml}$ of $1 \mathrm{M} \mathrm{NH}_{4} 0 \mathrm{Ac}$, shaken for $5 \mathrm{~min}$ and filtered through Whatman No. 2 filter paper. Gravimetric water content of air-dried and field-moist soil was determined by oven drying a sub-sample at $105^{\circ} \mathrm{C}$ for at least 24 hours [18]. For KMoist, sub-sample was not air-dried but was sieved through a $2 \mathrm{~mm}$ sieve. Two grams of sieved field-moist soil was treated with $20 \mathrm{ml}$ of $\mathrm{NH}_{4} \mathrm{O}$ Ac by adjusting the molarity of extracting solution to $1 \mathrm{M}$ according to the moisture content of the sample.

Table 2. Corn production details for all experimental sites.

\begin{tabular}{|c|c|c|c|c|}
\hline Site & Corn variety & $\begin{array}{l}\text { Planting density } \\
\text {--seeds } \mathrm{ha}^{-1} \text {-- }\end{array}$ & Sowing date & Harvesting date \\
\hline Buffalo & Dekalb DKC 36-30 RIB & 80,000 & $5 / 15 / 2014$ & $10 / 8 / 2014$ \\
\hline Gardner & NuTech 5B782 & - & $5 / 18 / 2014$ & $9 / 24 / 2014$ \\
\hline Walcott E & Dekalb DKC 36-30RIB & 85,000 & $5 / 30 / 2014$ & $10 / 15 / 2014$ \\
\hline Wyndmere & Dekalb DKC 43-10 & 87,250 & $5 / 27 / 2014$ & $10 / 14 / 2014$ \\
\hline Fairmont & GC 95-33 VT3P & 87,340 & $5 / 23 / 2014$ & $10 / 16 / 2014$ \\
\hline Milnor & Pioneer 9917 & 81,250 & $5 / 17 / 2014$ & $10 / 14 / 2014$ \\
\hline Walcott W & Dekalb 39-07 & 85,000 & $5 / 23 / 2014$ & $10 / 15 / 2014$ \\
\hline Arthur & ProSeed 11-91 VT2P RIB & 90,000 & $5 / 18 / 2014$ & $10 / 3 / 2014$ \\
\hline Page & REA 2A550 & - & $5 / 25 / 2014$ & $10 / 17 / 2014$ \\
\hline Valley City & Crop Plan 2417 VT2 & 75,000 & $5 / 5 / 2014$ & $10 / 13 / 2014$ \\
\hline
\end{tabular}


Table 3. Soil test results of initial soil samples collected from $0-15 \mathrm{~cm}$ depth.

\begin{tabular}{|c|c|c|c|c|c|c|c|c|}
\hline \multirow[t]{2}{*}{ Location } & $\mathrm{NO}_{3}-\mathrm{N}^{\dagger}$ & $\mathbf{P}^{\S}$ & $\mathbf{K}^{\pi}$ & \multirow[t]{2}{*}{$\mathbf{p} \mathbf{H}^{\#}$} & \multirow{2}{*}{$\begin{array}{c}\mathbf{E C}^{\dagger \dagger} \\
\mathbf{d S} \cdot \mathbf{m}^{-1}\end{array}$} & $\mathbf{O} \mathbf{M}^{\ddagger \ddagger}$ & Clay ${ }^{\S \S}$ & \multirow{2}{*}{$\begin{array}{c}\mathrm{CEC}^{\text {qศ }} \\
\mathrm{cmol}^{\mathrm{kgg}}{ }^{-1}\end{array}$} \\
\hline & $\mathrm{kg} \cdot \mathrm{ha}^{-1}$ & \multicolumn{2}{|c|}{---ppm-- } & & & \multicolumn{2}{|c|}{-----\%---- } & \\
\hline Buffalo & 18 & 12 & 115 & 7.6 & 0.19 & 2.1 & 10.8 & 12.9 \\
\hline Gardner & 10 & 13 & 110 & 5.9 & 0.09 & 2.2 & 11.3 & 12.5 \\
\hline Walcott E & 6 & 3 & 105 & 7.4 & 0.45 & 2.3 & 11.5 & 12.1 \\
\hline Wyndmere & 20 & 8 & 100 & 7.9 & 0.27 & 2.3 & 11.5 & 15.6 \\
\hline Fairmount & 23 & 10 & 140 & 7.6 & 0.30 & 2.7 & 15.5 & 19.9 \\
\hline Milnor & 9 & 18 & 110 & 6.2 & 0.43 & 2.2 & 7.30 & 14.1 \\
\hline Walcott W & 10 & 16 & 80 & 5.8 & 0.10 & 1.5 & 4.50 & 10.6 \\
\hline Arthur & 15 & 10 & 170 & 8.2 & 0.26 & 3.1 & 14.5 & 23.1 \\
\hline Page & 20 & 12 & 200 & 7.5 & 0.48 & 2.4 & 10.0 & 14.9 \\
\hline Valley City & 10 & 27 & 485 & 6.5 & 0.30 & 3.1 & 17.5 & 19.7 \\
\hline
\end{tabular}

${ }^{\dagger} \mathrm{NO}_{3}-\mathrm{N}$ extracted with water, ${ }^{\S} \mathrm{P}$ extracted with Olsen procedure, ${ }^{\top} \mathrm{K}$ extracted with $1 \mathrm{M}$ ammonium acetate, ${ }^{\#} \mathrm{pH}$ in water, ${ }^{\dagger \dagger} \mathrm{EC}$ using $1: 1$ (soil:water) ratio, ${ }^{\sharp}$ Organic matter-Loss on Ignition method, ${ }^{\S}$ Clay $(\%)$-Hydrometer method, ${ }^{\pi}$ Cation Exchange capacity estimated by $1 \mathrm{M}$ sodium acetate method.

The resulting slurry was then shaken for 5 min and filtered through Whatman No-2 filter paper. Soil K concentration of filtrate was determined with necessary dilutions using a Buck Scientific Atomic Absorption Spectrometer-Model 200A (Norwalk, CT, USA) using $766.5 \mathrm{~nm}$ wavelength.

\subsection{Yield Analysis}

For yield analysis, corn ears were harvested from one of the middle two rows leaving first and last plant in each row. Ears were shelled and grain weight was measured in grams. Grain moisture and test weight were measured

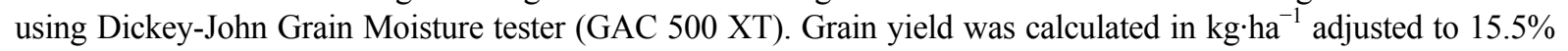
grain moisture content.

\subsection{Statistical Analysis}

Statistical software-SAS 9.3 and SAS Enterprise Guide 4.3 were used for data analyses [19] [20]. Linear regression was imposed on KDry and KMoist collectively over all sites as well as separately at very low, low, medium, high and very high K soil test K-levels. Pearson correlation coefficients were used to evaluate the relationship of KDry/KMoist ratio with clay content, soil moisture, cation exchange capacity, organic matter, and $(\mathrm{Ca}+\mathrm{Mg}) / \mathrm{K}$ at $\mathrm{p}<0.10$. Analysis of variance for yield response was calculated by SAS PROC GLM procedure using Randomized Complete Block Design with K-fertilizer rates as the main factor. Means of main effects were compared using Fisher's least significant difference (LSD) at 90\% confidence level.

\section{Results and Discussion}

\subsection{Basic Soil Properties}

Initial soil test results of all experimental sites are presented in Table 3. The $\mathrm{pH}$ of soils ranged from moderately acidic to moderately alkaline [21]. Based upon the EC levels, all sites had non-saline soils [22]. Seven of the total sites had sandy loam texture, while two of them had loam and one of the sites was categorized as loamy sand. Organic matter determined by loss of weight on Ignition method [23] ranged from $1.5 \%$ to $3.1 \%$. The CEC level of soils varied from 10.6 to $23.1 \mathrm{cmol} \cdot \mathrm{kg}^{-1}$.

\subsection{Comparison of Soil Potassium Test Based upon Air-Dried and Field Moist Samples}

Soil test-K values of surface soil samples $(0-15 \mathrm{~cm}$ depth) determined by KDry ranged from 21 ppm to 824 $\mathrm{ppm}$ across all sites with an average of $93 \mathrm{ppm}$. The KMoist test values had an average of $99 \mathrm{ppm}$ with $\mathrm{K}$ values 
ranging from $14 \mathrm{ppm}$ to $837 \mathrm{ppm}$. On average, KDry test of surface soils $(0-15 \mathrm{~cm})$ were 1.07 times higher in $\mathrm{K}$ compared to KMoist values but the change of Soil K test varied between soils. Out of 366 soil samples, $47 \%$ showed a decrease in $\mathrm{K}$ content upon drying while $53 \%$ of samples showed an increase in $\mathrm{K}$ content. The ratio of KDry/KMoist varied from 0.32 to 2.66 across all sites for surface soil samples. The KDry of sub-surface soil samples $(15-30 \mathrm{~cm})$ was 1.52 times greater in K content compared with KMoist. Only $20 \%$ of the total samples showed a decrease in $\mathrm{K}$ content upon drying while $80 \%$ samples showed an increase in $\mathrm{K}$ values. The linear trend line deviated from the 1:1 line, with the greatest difference in the high and very high $\mathrm{K}$ range (Figure 2). Such variation in soil $\mathrm{K}$ levels of moist and dried soil samples had been observed in various earlier studies in Iowa [12] [24]

Since the variation between KDry and KMoist was different for different sites throughout the growing season, probable factors that might contribute to the difference in drying response were correlated to the KDry/KMoist ratio and summarized in Table 4.

Soil moisture content was poorly correlated $(r=-0.02)$ with KDry/KMoist ratio. Similar conclusions were found in Iowa where they determined $r^{2}=0.03$ between KDry and KMoist ratio and soil moisture [12]. Clay percentage of initial soil samples was not significantly correlated with ratio of KDry/KMoist $(r=0.45, p=0.19)$. Texture has previously been reported as the main factor for influencing of the degree of $\mathrm{K}$ release or fixation [25]. However, clay type may have influenced the KDry/KMoist ratio [26]. Presence of illite is usually responsible for release while montmorillonite (a smectitic clay) is known to fix $\mathrm{K}$ [10]. Analysis of clay mineralogy of all these sites might be more helpful in explaining the release and fixation of $\mathrm{K}$ upon drying than the determination of clay content of soil per se.

Ratio of $(\mathrm{Ca}+\mathrm{Mg}) / \mathrm{K}$ was significantly correlated with KDry/KMoist with a correlation coefficient $\mathrm{r}=0.64$ $(\mathrm{p}<0.10)$. A relationship between $(\mathrm{Ca}+\mathrm{Mg}) / \mathrm{K}$ and $\mathrm{KDry} / \mathrm{KMoist}$ was also reported by Barbagelata and Mal-

(a)

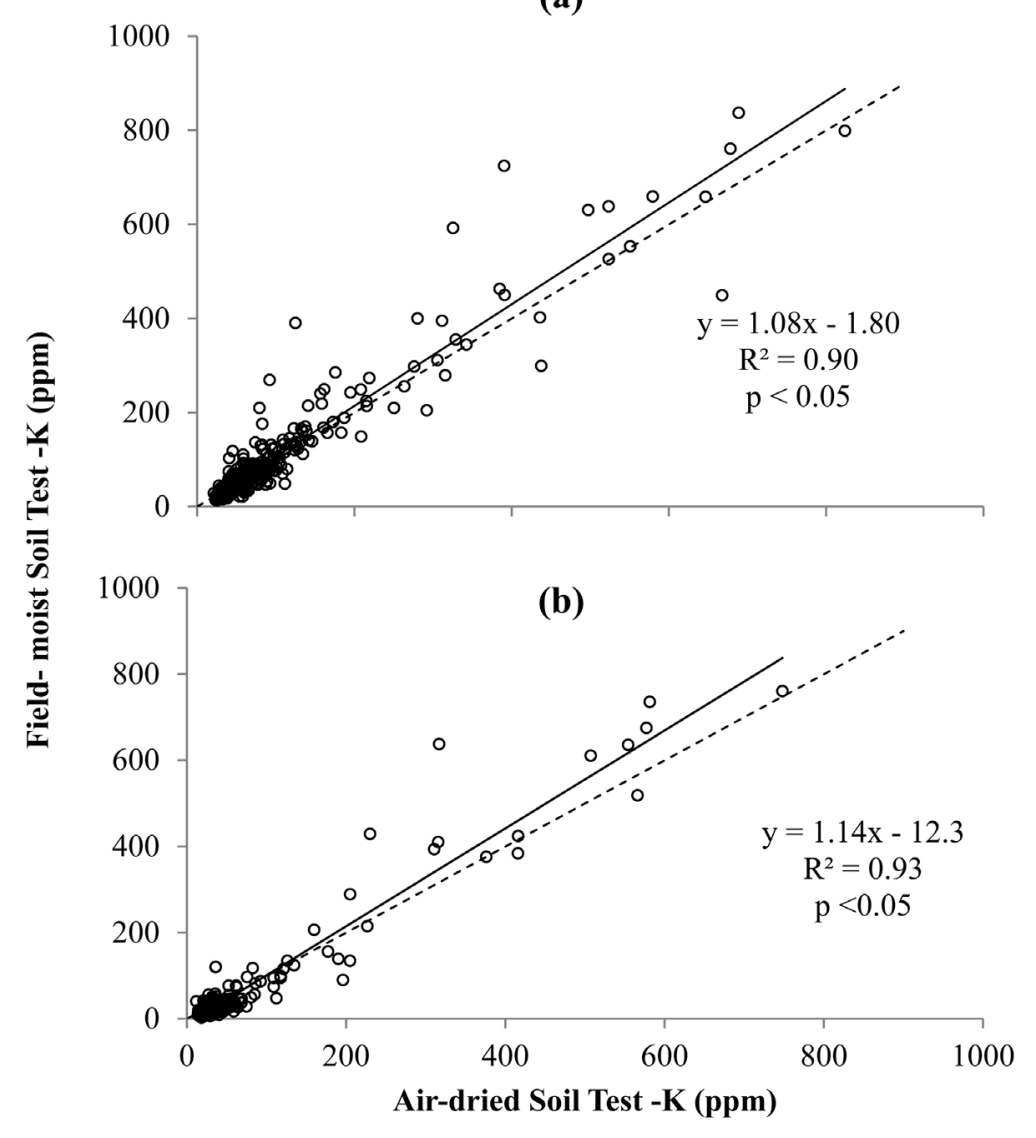

Figure 2. Relationship between soil K-test values based upon air-dried and fieldmoist soil samples of (a) $0-15 \mathrm{~cm}$ and (b) $15-30 \mathrm{~cm}$ depth. 
Table 4. Soil test results of initial soil samples collected from $0-15 \mathrm{~cm}$ depth.

\begin{tabular}{|c|c|c|}
\hline Soil properties & Number of observations (n) & Pearson correlation coefficient $(r)$ \\
\hline \multicolumn{3}{|l|}{ Initial soil samples } \\
\hline pH & 10 & 0.29 \\
\hline Organic matter $(\%)$ & 10 & $0.61^{*}$ \\
\hline Cation exchange capacity $\left(\mathrm{cmol} \cdot \mathrm{kg}^{-1}\right)$ & 10 & $0.63^{*}$ \\
\hline Electrical conductivity $\left(\mathrm{dS} \cdot \mathrm{m}^{-1}\right)$ & 10 & 0.29 \\
\hline Clay (\%) & 10 & 0.45 \\
\hline \multicolumn{3}{|l|}{ Others } \\
\hline$(\mathrm{Ca}+\mathrm{Mg}) / \mathrm{K}$ ratio $^{\dagger}$ & 40 & $0.64^{*}$ \\
\hline Soil moisture $(\%)^{\ddagger}$ & 366 & -0.02 \\
\hline
\end{tabular}

*Significant at $90 \%$ confidence level, ${ }^{\dagger}$ Correlation of $(\mathrm{Ca}+\mathrm{Mg}) / \mathrm{K}$ ratio with $\mathrm{KDry} / \mathrm{KM}$ oist ratio of soil samples collected in first fortnight of September, ${ }^{\ddagger}$ Correlation of soil moisture (\%) with KDry/KMoist ratio of all soil samples collected at fortnightly interval during the corn growing season.

larino [12]. It signifies that the concentration of cations present in soil solution can affect the release and fixation of K upon drying. It occurs because cations such as calcium which show high affinity for negative charged clays can compete with potassium ions for $\mathrm{K}$ fixation inducing wedge zones within clay interlayers which results in a release of $\mathrm{K}$ ions into the soil solution [27].

KDry and KMoist were significantly related for both depths $(0-15 \mathrm{~cm}$ and $15-30 \mathrm{~cm})$. Potassium levels of sub-soil samples were always lower in K compared to surface soil samples. Overall, sub-surface soils showed an appreciable increase in K levels in KDry compared to KMoist tests of surface soil samples. Since the sub-surface soils are less prone to weathering compared to surface soils, thereby, they show a high potential of release of K upon drying [10].

KDry compared to KMoist were significantly related in very low, low and very high category K soils (Figure 3). When the KDry content was below 120 ppm, K was released upon drying. Dry K analysis gave lower K values when the soils had $>120 \mathrm{ppm}$ initial K. Barbagelata and Mallarino results agree with these data where an exponential decrease of KDry/KMoist ratios was observed as soil K levels were increased [12].

Cation exchange capacity was correlated $(\mathrm{r}=0.63, \mathrm{p}<0.10)$ with the KDry/KMoist ratio. The CEC of a soil partially depends upon the amount and type of clay minerals. CEC was observed to be positively related to the change of $\mathrm{K}$ levels in the soil samples when exposed to drying [28].

KDry/KMoist ratio was significantly related to organic matter content with a correlation coefficient of $\mathrm{r}=$ $0.61(\mathrm{p}<0.10)$. The relationship of organic matter (non-volatile organic compounds) to the release of $\mathrm{K}$ from soils upon drying is also noted by Welch and Flannery [29] where organic compounds were found to retard the process of diffusion of $\mathrm{K}$ from interlayer of clay minerals.

As the season progressed, the difference between KDry and KMoist also changed (Figures 4-6). During April, with the exceptions of the Milnor and Arthur sites, KMoist levels were greater than KDry. By late September, this trend was reversed; KDry levels were greater K as compared to KMoist.

\subsection{Effect of Time of Sampling on Soil K Test Results}

Soil KDry levels of all sites decreased as the growing season progressed (Figures 4-6). This change was greater in Very high- K soils as compared to low K soils. There was a decrease of 265 ppm of K content at Valley City (Very high K-site) at the end of September as compared to those collected the previous April. In comparison, the decrease in $\mathrm{K}$ between April and September was only $25 \mathrm{ppm}$ at Walcott West (Low K site). Greater variation of $\mathrm{K}$ levels in high $\mathrm{K}$ soils was also reported previously [30]. Temporal change of soil K level was significantly correlated with soil moisture content at three sites (Buffalo, Walcott East and Wyndmere) while temporal changes of $\mathrm{K}$ at other sites were poorly correlated with soil moisture content. An increase in non-exchangeable $\mathrm{K}$ was also observed by September in all sites except at Valley City. The temporal variation of soil K can at least be partially attributed to changing soil moisture and a reversion of exchangeable $\mathrm{K}$ to non-exchangeable forms. In addition, plant uptake during the growing season and leaching of $\mathrm{K}$ after physiological maturity until har- 


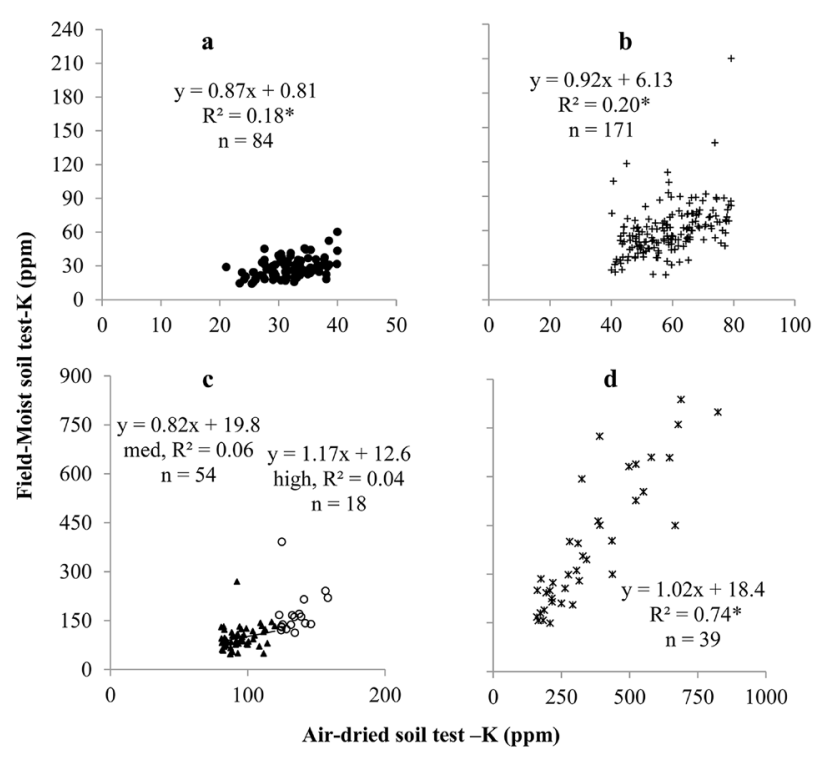

*refers to significant relation between soil test $\mathrm{K}$ results based upon air-dried and fieldmoist soils at $95 \%$ confidence level.

Figure 3. Relation of soil test $\mathrm{K}$ results based upon air-dried and field-moist soil samples of (a) Very low (0 - 40 ppm) soil K samples (b) Low (41 - $80 \mathrm{ppm}$ ) soil K sample (c) Medium (81 $120 \mathrm{ppm})$ and high (121 - $160 \mathrm{ppm})$ soil K samples (d) Very high (>161 ppm) soil K samples.
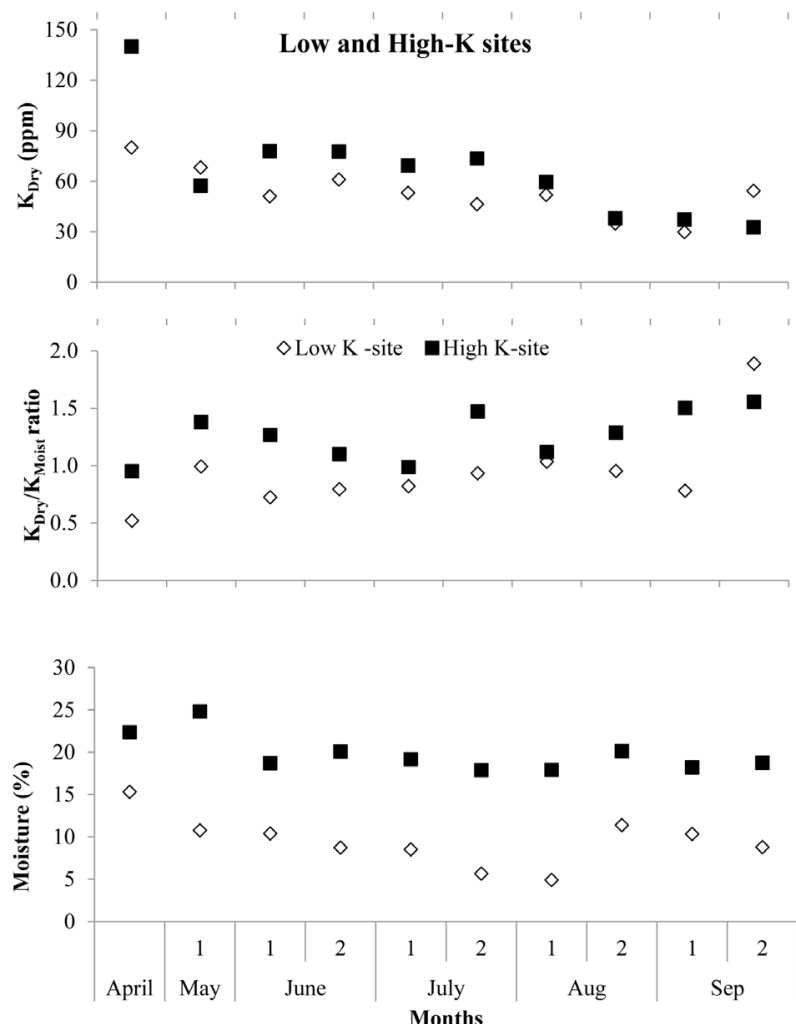

Figure 4. Effect of time of sampling on soil test-K (ppm), KDry/ KMoist ratio and soil moisture (\%) at Walcott W (low K site) and Fairmount (High K site). 

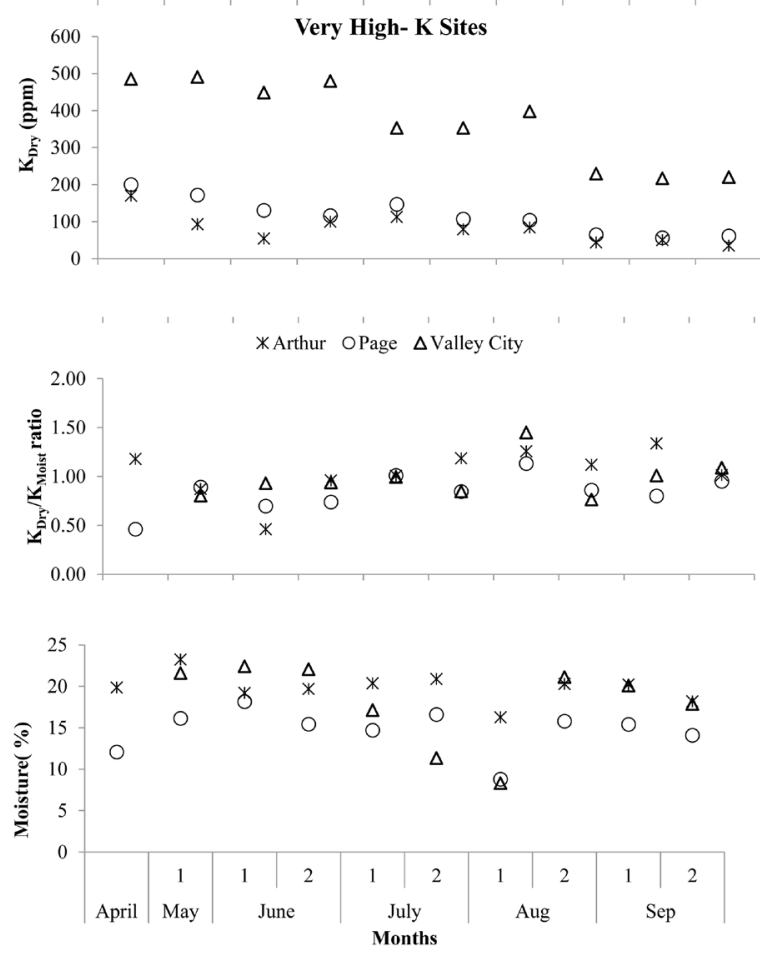

Figure 5. Effect of time of sampling on soil test-K (ppm), KDry/KMoist ratio and soil moisture (\%) at Very high K testing sites (Arthur, Page and Valley City).
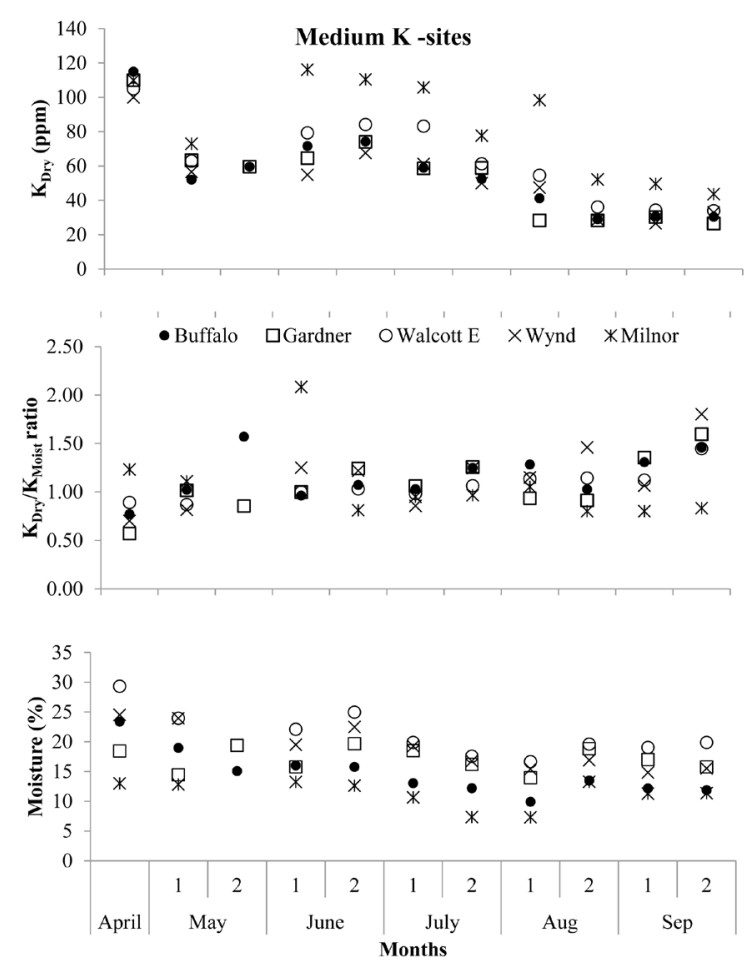

Figure 6. Effect of time of sampling on soil test-K (ppm), $\mathrm{KDry} / \mathrm{KMoist}$ ratio and soil moisture (\%) at medium K testing sites (Buffalo, Gardner, Walcott E, Wyndmere and Milnor). 
vesting have been reported as the other possible factors responsible for temporal $\mathrm{K}$ variations [14].

Except at the Valley City site, soil K level of all sites dropped to Very low and Low categories with time (Table 5). Lower $\mathrm{K}$ levels during the fall may mislead farmers in applying fertilizer $\mathrm{K}$ rates for next year's crop. However, soil $\mathrm{K}$ levels usually recover during the winter season due to freezing and thawing effect and leaching of $\mathrm{K}$ from the crop residues, and comparatively higher exchangeable K is observed in April and May [31] [32]. It may be necessary to construct critical levels for early fall and June soil sampling, where the soil $\mathrm{K}$ levels are more stable over a practical length of time.

Among the KDry and KMoist soil test results, moist K soil levels were observed to be more variable within a corn growing season. Except for Arthur site, the coefficient of variation was greater for KMoist soil results compared with KDry for all other sites (Table 6). Some possible reasons for higher variation in KMoist results could be the manual error during molarity adjustments of extracting solution and while mixing of the moist samples to get a representative sample. This indicates that the current methodology used in determining soil $\mathrm{K}$ involving air-drying as a pre-treatment, have more potential in providing precise estimates of $\mathrm{K}$ levels over a growing season.

\subsection{Corn Response to Applied K Fertilizer Rates}

Experimental locations were quite variable in K-status, varying from $80 \mathrm{ppm}$ to $485 \mathrm{ppm}$ of plant available KDry levels. According to North Dakota's published K fertility categories [33], five of the sites had medium soil $\mathrm{K}$ level, three had soil $\mathrm{K}$ levels in the very high category while low and high categories were represented by one site each. Potassium in the profile was stratified; surface samples $(0-15 \mathrm{~cm})$ had higher $\mathrm{K}$ levels than the sub- surface layer $(15-30 \mathrm{~cm})$.

Corn grain yield was increased at four sites at the $10 \%$ probability level compared to plots receiving no K application. Maximum yield was obtained at $101 \mathrm{~kg} \cdot \mathrm{ha}^{-1}$ fertilizer rate at 5 sites and at $67 \mathrm{~kg} \cdot \mathrm{ha}{ }^{-1} \mathrm{~K}$ rate over 4 out of 10 sites. None of the sites gave highest yield at maximum K fertilizer rate of $168 \mathrm{~kg} / \mathrm{ha}$ of K. Only one site achieved maximum response at $134 \mathrm{~kg} / \mathrm{ha}$ of $\mathrm{K}$ rate (Table 7). The present $\mathrm{K}$ category recommendations based on KDry predicted crop response at only 3 of 10 locations. The KMoist did not improve crop response prediction. In addition, the non-exchangeable $\mathrm{K}$ levels were not helpful in predicting crop response.

North Dakota experienced frequent rain in the spring and summer of 2014 (NDAWN, http://ndawn.ndsu.nodak.edu/) and good soil moisture conditions were maintained until August. Favorable soil moisture conditions promotes diffusion of $\mathrm{K}^{+}$ions [34]-[36] and may have resulted in comparable yields of control plots as that of plots receiving K-fertilizer.

Table 5. Changes in soil test $\mathrm{K}$ level between spring and fall soil sampling of control plots and its impact on soil test category.

\begin{tabular}{cccc}
\hline \multirow{2}{*}{ Location } & Change in soil K level & & Soil test category $^{*}$ \\
\cline { 2 - 4 } & ppm & Spring & Fall \\
\hline Buffalo & $84.5 \pm 5.35^{\ddagger}$ & Medium & Very low \\
Gardner & $83.5 \pm 4.44$ & Medium & Very low \\
Walcott E & $71.1 \pm 2.87$ & Medium & Very low \\
Wyndmere & $67.2 \pm 3.85$ & Medium & Very low \\
Fairmount & $107 \pm 3.85$ & High & Very low \\
Milnor & $66.3 \pm 2.53$ & Medium & Low \\
Walcott W & $25.8 \pm 10.6$ & Low & Low \\
Arthur & $134 \pm 9.66$ & Very high & very low \\
Page & $139 \pm 7.79$ & Very high & Very low \\
Valley City & $265 \pm 67.0$ & Very high & Very high \\
\hline
\end{tabular}

${ }^{\dagger}$ Change in soil test $\mathrm{K}$ level calculated as spring minus fall sampling soil $\mathrm{K}$ test results. ${ }^{\dagger}$ Standard deviation of soil $\mathrm{K}$ change between four replications of a control plot $(\mathrm{n}=4)$. * Soil test categories are given for corn in Franzen $(2010)$ Extension Bulletin which include five categories as very low $(0$ - 40 ppm), low (41 - $80 \mathrm{ppm})$, medium (81 - $120 \mathrm{ppm})$, high (121 - $160 \mathrm{ppm})$ and very high (>161 ppm). 
Table 6. Summary of soil K tests based on air-dried and field-moist soil samples during the growing season.

\begin{tabular}{ccccccc}
\hline \multirow{2}{*}{ Location } & \multicolumn{3}{c}{ Dry soil K test (ppm) } & \multicolumn{3}{c}{ Moist soil K test (ppm) } \\
\cline { 2 - 7 } & Average & Std. Dev. & $\mathbf{C V}^{\dagger}$ & Average & Std. Dev. & CV \\
Buffalo & 55.95 & 25.18 & 0.45 & 54.15 & 36.31 & 0.67 \\
Gardner & 54.78 & 25.39 & 0.46 & 59.93 & 47.59 & 0.79 \\
Walcott E & 63.50 & 24.39 & 0.38 & 63.59 & 29.73 & 0.47 \\
Wyndmere & 52.58 & 21.71 & 0.41 & 53.15 & 36.79 & 0.69 \\
Fairmount & 66.32 & 31.00 & 0.47 & 56.63 & 35.62 & 0.63 \\
Milnor & 83.70 & 28.03 & 0.33 & 81.45 & 30.56 & 0.38 \\
Walcott W & 53.06 & 14.68 & 0.28 & 64.04 & 35.24 & 0.55 \\
Arthur & 82.29 & 40.16 & 0.49 & 83.84 & 38.38 & 0.46 \\
Page & 115.9 & 47.96 & 0.41 & 156.9 & 109.2 & 0.70 \\
Valley City & 360.9 & 108.3 & 0.30 & 391.3 & 136.5 & 0.35 \\
\hline
\end{tabular}

${ }^{\dagger} \mathrm{CV}$ refers to coefficient of variation.

Table 7. Summary of soil K tests based on air-dried and field-moist soil samples during the growing season.

\begin{tabular}{|c|c|c|c|c|c|c|c|}
\hline \multirow{2}{*}{ Location } & \multicolumn{7}{|c|}{ Treatment $\left(\mathrm{kg} \mathrm{K}_{2} \mathrm{O} \mathrm{ha}^{-1}\right)$} \\
\hline & $\mathbf{0}$ & 33 & 67 & 101 & 134 & 168 & LSD \\
\hline & \multicolumn{7}{|c|}{-----(Grain yield, $\left.\mathrm{Mg} \cdot \mathrm{ha}^{-1}\right)$------ } \\
\hline Buffalo & $8.69 \mathrm{c}^{\dagger}$ & $9.64 \mathrm{a}$ & $8.88 \mathrm{bc}$ & $9.86 \mathrm{a}$ & $9.38 \mathrm{ab}$ & $9.31 \mathrm{ab}$ & $0.57^{*}$ \\
\hline Gardner & $8.94 \mathrm{~b}$ & $10.91 \mathrm{a}$ & $9.75 \mathrm{ab}$ & $11.0 \mathrm{a}$ & $10.1 \mathrm{ab}$ & $9.84 \mathrm{ab}$ & $1.43^{*}$ \\
\hline Walcott E & 7.07 & 7.80 & 7.26 & 7.93 & 7.05 & 7.32 & $\mathrm{~ns}^{\ddagger}$ \\
\hline Wyndmere & 8.44 & 9.42 & 10.56 & 8.42 & 9.31 & 8.18 & ns \\
\hline Fairmount & $10.1 \mathrm{~b}$ & $10.9 \mathrm{ab}$ & $11.3 \mathrm{ab}$ & $11.0 \mathrm{ab}$ & $11.4 \mathrm{a}$ & $10.8 \mathrm{ab}$ & $1.27^{*}$ \\
\hline Walcott W & 8.18 & 8.40 & 8.85 & 8.54 & 8.78 & 8.70 & ns \\
\hline Arthur & $9.77 \mathrm{c}$ & $10.2 \mathrm{bc}$ & $11.3 \mathrm{ab}$ & $11.7 \mathrm{a}$ & $11.1 \mathrm{ab}$ & $10.6 \mathrm{abc}$ & $1.26^{*}$ \\
\hline Page & $9.34 \mathrm{a}$ & $8.85 \mathrm{ab}$ & $9.74 \mathrm{a}$ & $9.49 \mathrm{a}$ & $9.03 \mathrm{ab}$ & $8.32 \mathrm{~b}$ & $1.01^{*}$ \\
\hline \multirow[t]{3}{*}{ Valley City } & 9.74 & 9.62 & 9.64 & 11.1 & 10.0 & 10.7 & $\mathrm{~ns}$ \\
\hline & \multicolumn{7}{|c|}{ Treatment $\left(\mathrm{kg} \mathrm{K}_{2} \mathrm{O} \mathrm{ha}^{-1}\right)$} \\
\hline & 0 & 67 & 134 & 202 & 269 & 336 & \\
\hline Milnor & $12.3 \mathrm{ab}$ & $13.0 \mathrm{a}$ & $11.9 \mathrm{~b}$ & $11.8 \mathrm{~b}$ & $12.0 \mathrm{ab}$ & $12.8 \mathrm{ab}$ & $1.06^{*}$ \\
\hline
\end{tabular}

${ }^{*}$ Significant at $90 \%$ confidence level, ${ }^{\dagger}$ Different letters indicate significant differences at 0.10 significance level. ${ }^{\star}$ refers to non-significant corn yield response to applied K-treatments.

Based upon the observations of corn response to applied fertilizers, it can be concluded that a refined strategy is required to better predict corn yield response, or a different soil testing method is required for prediction improvement.

\section{Summary and Conclusions}

Air-drying of soil samples prior to soil analysis of plant-available $\mathrm{K}$ significantly affected soil $\mathrm{K}$ test results. Change of soil K test levels due to air-drying was not consistently increased or decreased, and was found to be significantly related to cation exchange capacity, organic matter and $(\mathrm{Ca}+\mathrm{Mg}) / \mathrm{K}$ ratio of the soil samples. Soil moisture content, clay content, $\mathrm{pH}$ and $\mathrm{EC}$ showed minimal influence over KDry/KMoist ratios. Time of soil sampling had considerable effects on soil K levels as well as KDry/KMoist ratios. Temporal K-variations of soil samples collected in fall and spring were large enough to change the soil test interpretation category of a site for 
making fertilizer recommendations, unless soil test interpretations were constructed for different sampling times. Corn response to applied $\mathrm{K}$ fertilizer was site specific and only related to initial soil $\mathrm{K}$ levels at three of ten sites.

Based upon these results, it can be concluded that air-drying of soil sample prior to soil $\mathrm{K}$ analysis alters the actual plant available-K levels, but KMoist is not a better predictor of corn yield response compared with KDry. The extent of $\mathrm{K}$ variation is dependent upon various factors and is likely to change over the time. Corn $\mathrm{K}$ response curves needs recalibration in North Dakota. Moreover, soil K levels along with time of sampling, soil moisture dynamics and plant's nutrient utilization potential should be taken into consideration when making Kfertilizer recommendations.

\section{References}

[1] National Agricultural Statistical Service (2011) Corn for Grain Yield Per Acre-North Dakota. U.S. Department of Agriculture, Washington DC.

http://quickstats.nass.usda.gov/results/90C69DEC-38D6-31B4-9953-4C6EB5E82D79?pivot=short desc

[2] Ransom, J., Franzen, D., Glogoza, P., Hellevang, K., Hofman, V., McMullen, M. and Zollinger, R. (2004) Basics of Corn Production in North Dakota. North Dakota Extension Service. A-834. http://www.ag.ndsu.edu/pubs/plantsci/rowcrops/a834.pdf

[3] Bender, R.R., Haegele, J.W. Ruffo, M.L. and Below, F.E. (2013) Modern Corn Hybrids' Nutrient Uptake Patterns. Better Crops, 97, 7-10.

[4] Hanway, J.J. (2007) Iowa State University Research. Integrated Crop, 498, 251-253. http://www.ipm.iastate.edu/ipm/icm/2007/8-6/nutrients.html

[5] Havlin. J.L., Beaton, J.D., Tisdale, S.M. and Nelson, W.L. (2005) Potassium. In: Havlin, J.L., et al., Eds., Soil Fertility and Fertilizers, Pearson Prentice Hall, New Jersey, 199-218.

[6] Hu, Y. and Schmidhater, U. (2005) Drought and Salinity: A Comparison of Their Effects on Mineral Nutrition of Plants. Journal of Plant Nutrition and Soil Science, 168, 541-549. http://dx.doi.org/10.1002/jpln.200420516

[7] Cakmak, I. (2005) The Role of Potassium in Alleviating Detrimental Effects of Abiotic Stresses in Plants. Journal of Plant Nutrition and Soil Science, 168, 521-530. http://dx.doi.org./10.1002/jpln.200420485

[8] Zorb, C., Senbayram, M. and Peiter, E. (2013) Potassium in Agriculture-Status and Perspectives. Journal of Plant Physiology, 171, 656-669. http://dx.doi.org/10.1016/j.jplph.2013.08.008

[9] Haby, V.A., Russelle, M.P. and Skogley, E.O. (1990) Testing Soils for Potassium, Calcium and Magnesium. In: Westerman, R.L., Ed., Soil Testing and Plant Analysis, 3rd Edition, SSSA, Madison, 181-221.

[10] McLean, E.O. and Watson, M.E. (1985) Soil Measurements of Plant Available Potassium. In: Munson, R.D., Ed., Potassium in Agriculture, ASA, CSSA, and SSSA, Madison, 277-308.

[11] Wells, K.L. and Dollarhide, J.E. (2000) The Effect of Drying Soil Samples on Soil Test Potassium Values. Agronomy Notes, 32. http://www.uky.edu/Ag/Tobacco/agr notes/agvl32 5.pdf

[12] Barbagelata, P.A. and Mallarino, A.P. (2012) Field Correlation of Potassium Soil Test Methods Based on Dried and Field-Moist Soil Samples for Corn and Soybean. Soil Science Society of America Journal, 77, 630-642.

[13] Franzen, D.W. (2011) Variability of Soil Test Potassium in Space and Time. Proceedings of the North Central Extension-Industry Soil Fertility Conference, Des Moines, 16-17 November 2011, 74-82.

[14] Murrell, T.S. (2011) Why Are Soil Test Potassium Levels So Variable over Time in the Corn Belt? http://fyi.uwex.edu/discoveryfarms/files/2011/06/murrell-k-variability.pdf

[15] Vitko, L.F., Laboski, C.A.M. and Andraski, T.W. (2010) Effect of Sample Time on Soil Test Potassium Levels. Proceedings of Wisconsin Crop Management Conference, 49, 32-38.

[16] Elliott, E.T., Heil, J.W., Kelly, E.F. and Monger, H.C. (1999) Soil Structural and Other Physical Properties. In: Robertson, G.P., et al., Eds., Standard Soil Methods for Long Term Ecological Research, Oxford University Press, Inc., New York, 74-88.

[17] Chapman, H.D. (1965) Cation-Exchange Capacity. In: Black, C.A., Ed., Method of Soil Analysis, Part 2: Chemical and Microbiological Properties, ASA, Madison, 891-900.

[18] Black, C.A. (1965) Methods of Soil Analysis: Part 1, Physical and Mineralogical Properties. American Society of Agronomy, Madison.

[19] SAS Institute (2013) SAS Version 9.3. SAS Inst., Cary.

[20] SAS Institute (2013) SAS Enterprise Guide 4.3. SAS Inst., Cary.

[21] Soil Survey Division Staff (1993) Soil Survey Manual. Soil Conservation Service. US Department of Agriculture 
Handbook 18.

[22] Whitney, D.A. (1998) Soil Salinity. In: Brown, J.R., Ed., Recommended Chemical Soil Test Procedures for the North Central Region, NCR Publication No. 221, Missouri Agricultural Experiment Station, Columbia, 59-60.

[23] Combs, S.M. and Nathan, M.V. (1998) Soil Organic Matter. In: Brown, J.R., Ed., Recommended Chemical Soil Test Procedures for the North Central Region, NCR Publication No. 221, Missouri Agricultural Experiment Station SB 1001, University of Missouri-Columbia, Columbia, 53-58.

[24] Luebs, R.E., Stanfoed, G. and Scott, A.D. (1956) Relation of Available Potassium to Soil Moisture. Soil Science Society of America Journal, 20, 45-50. http://dx.doi.org/10.2136/sssaj1956.03615995002000010011x

[25] Burns, A.F. and Barber, S.A. (1961) The Effect of Temperature and Moisture on Exchangeable Potassium. Soil Science Society of America Proceedings, 23, 349-352. http://dx.doi.org/10.2136/sssaj1961.03615995002500050013x

[26] Dowdy, R.H. and Hutcheson, T.B. (1963) Effect of Exchangeable Potassium Level and Drying on Release and Fixation of Potassium by Soils as Related to Clay Mineralogy. Soil Science Society of America Journal, 27, 31-34. http://dx.doi.org/10.2136/sssaj1963.03615995002700010014x

[27] Sparks, D.L. and Huang, P.M. (1985) Physical Chemistry of Soil Potassium. In: Munson, R.D., Ed., Potassium in Agriculture, ASA, CSSA and SSSA, Madison, 201-265.

[28] Barbagelata, P.A. (2006) Evaluation of Potassium Soil Tests and Methods for Mapping Soil Fertility Properties in Iowa Corn and Soybean Fields. Retrospective Thesis and Dissertations, Paper 1797, Ph.D. Dissertation, Iowa State University, Ames.

[29] Welch, L.F. and Flannery, R.L. (1985) Potassium Nutrition of Corn. In: Munson, D.R., Ed., Potassium in Agriculture, ASA, CSSA and SSSA, Madison, 647-664.

[30] Lockman, R.B. and Malloya, M.G. (1984) Seasonal Variation in Soil Test Results. Communications in Soil Science and Plant Analysis, 15, 741-757. http://dx.doi.org/10.1080/00103628409367514

[31] Fine, L.O., Bailey, T.A. and Truog, E. (1940) Availability of Fixed Potassium as Influenced by Freezing and Thawing. Soil Science Society of America Proceedings, 5, 183-186. http://dx.doi.org/10.2136/sssaj1941.036159950005000C0031x

[32] Mallarino, A.P., Barbagelata, P.A., Clover, M.W., Villavicencio, C.X. and Thompson, L.B. (2011) Factors Determining High Temporal Soil-Test Potassium Variation and Soil Sampling and Testing Alternatives. Proceedings of the North Central Region Soil and Plant Analyst Workshop, Bettendorf, IA, 23-24 February 2011, 3-14.

[33] Franzen, D.W. (2010) North Dakota Fertilizer Recommendation Tables and Equations. NDSU Extension Service, SF-882 (Revised), 7.

[34] Mackay, A.D. and Barber, S.A. (1985) Soil Moisture Effect on Potassium Uptake by Corn. Agronomy Journal, 77, 524-527. http://dx.doi.org/10.2134/agronj1985.00021962007700040005x

[35] Schaff, B.E. and Skogley, E.O. (1982) Diffusion of Potassium, Calcium and Magnesium in Bozeman Silt Loam as Influenced by Temperature and Moisture. Soil Science Society of America Journal, 46, 521-524.

[36] Zeng, Q. and Brown, P.H. (2000) Soil Potassium Mobility and Uptake by Corn under Differential Soil Moisture Regimes. Plant and Soil, 221, 121-134. 